\title{
Gin Chinese
}

National Cancer Institute

\section{Source}

National Cancer Institute. Gin Chinese. NCI Thesaurus. Code C158200.

A Chinese person from the Gin ethnic group. 